\title{
IMPACT OF SCHOOL DROPOUT ON HUMAN DEVELOPMENT IN BANGLADESH
}

\author{
MUKTASHA DEENA CHOWDHURY \\ Assistant Professor (Statistics), Department of Business Administration, \\ Asian University of Bangladesh, Bangladesh \\ *(muktasha@gmail.com)
}

This journal is licensed under a Creative Commons Attribution-NonCommercial 4.0 International License (CC-BY-NC). Articles can be read and shared for noncommercial purposes under the following conditions:

- BY: Attribution must be given to the original source (Attribution)

- NC: Works may not be used for commercial purposes (Noncommercial)

This license lets others remix, tweak, and build upon your work non-commercially, and although their new works must also acknowledge you and be non-commercial, they don't have to license their derivative works on the same terms. License Deed Link: http://creativecommons.org/licenses/by-nc/4.0/

Legal Code Link: http://creativecommons.org/licenses/by-nc/4.0/legalcode

$A B C$ Research Alert uses the CC BY-NC to protect the author's work from misuse.

\begin{abstract}
The Human Development Index (HDI) is the geometric mean of normalized indices for each of the three dimensions: Education Index, Life expectancy at birth and Gross National Income (GNI) per capita. As per Human Development Report of UNDP, Bangladesh was in 136th position among 189 countries in 2017. Education index is one of the important components of HDI of a country. The lack of education, forces the poor household to engage in less productive activities which results in lower GNI. Thus we can see that education has both direct and indirect influence on HDI of a country. Education index is the function of mean year of schooling and expected year of schooling. In 2015, dropout rates of secondary and primary schools were 40.29 percent, and 22.70 percent respectively. By reducing school dropout, the mean year of schooling of any country can be increased which results in a positive change in education index and thus human development index. The present research is an attempt to examine the influence of school dropout on Human Development Index. This study is based on both primary data and secondary data. Primary data have been collected through convenience sampling technique from 200 children who dropped out at different levels of primary and secondary schools in Bangladesh. Results show that the important reasons for school dropout are poor economic conditions, poor performance in school, less interest of parents, less interest of education, lack of school facilities, broken family, orphanage \& migration of parents. The study recommends some ways to reduce school dropout. The study also suggests that the mean year of schooling can be increased through the establishment of residential schools, night schools, and through implementing learn and earn scheme by the Government of Bangladesh or other organizations.
\end{abstract}

Keywords

School dropout, human development index, education index, mean year of schooling, expected year of schooling.

\section{INTRODUCTION}

The Human Development Index (HDI) is the geometric mean of normalized indices for each of the three dimensions: Education Index, Life expectancy at birth and Gross National Income (GNI) per capita. As per Human Development Report of UNDP, Bangladesh was in $136^{\text {th }}$ position among 189 
countries in 2017 (Source: UNDP). Education index is one of the important components of HDI of a country. The lack of education, forces the poor household to engage in less productive activities which results in lower GNI. Thus we can see that education has both direct and indirect influence on HDI of a country.

Education is important for a country to grow. Whether it is economically or socially, education plays a vital role in the growth of these two important factors. In the global perspective, it is an incontestable fact that the progress of a nation is highly dependent on the education of their citizens. It is widely acknowledged that education is the most important factors contributing to poverty alleviation. Education plays a central role and has a cross cutting impact on all aspects of human life. It is a vital investment for human and economic development. Dropping out is defined by National Center for Education Statistics as leaving school without completing a high school education or equivalent credential such as a General Educational Development (GED) certificate. Quality education can play dynamic role in productivity, social and economic growth of a country. In developing countries less attention is paid to improve quality of education and provision of education to people belongs to any class. In this regard, a UNESCO report (2000) on the state of the world's children, points out, that about one thirty million children in the developing world denied their right to education through Dropping out. A study in India researcher found the reasons of students' school dropouts, In India due to financial problems and expenses dropout rate is high. So students drop out their school to fulfill their financial needs. Another reason of students' dropouts is that some parents are not interested in education for their children. Dropout rate in Bangladesh is also high as in other developing countries. According to Bangladesh News.Com the year 2005 to 2006, 1.7 million students were enrolled in secondary education level but about 0.7 million students' dropout without completing their secondary education and higher secondary education examination in 2007. A total of 38.3 percent students in secondary level have dropped out in 2016, which is around two percent lower than that of the previous year, a report revealed today. The dropout rate was 40.29 percent in 2015 , according to the report of Bangladesh Bureau of Educational Information and Statistics (Banbeis).

In 2016, the dropout rate among girls in secondary level was 42.19 percent and among boys was 33.80 percent. In 2015, the rates were 45.92 percent and 33.72 percent respectively, the report said. At university level dropout rate is not different from secondary and higher secondary level. ASA University of Bangladesh start working in 2007 and number of enrolled students was larger than other private universities of Bangladesh. If there is less contribution of parents' interest for their Childs' education then there are greater possibilities of student dropout.

Findings of this research would be helpful for policy maker to control dropouts in educational institutes. These findings would be helpful for making policies to promote quality education in country that will help to increase literacy rate and economic progress. Quality education is most desirable objective of a country. It is fact that the country will grow where a large proportion of its budget is allocated on education.

\section{LITERATURE REVIEW}

When children are forced to work, they are often denied their rights to education, leisure and play. They are also exposed to situations that make them vulnerable to trafficking, abuse, violence and exploitation. Millions of children are reported not to attend school, however estimated vary (Md. Afzal Hossain, 2012).

According to ILO Convention, no 182, (1999) Child work is considered acceptable only when it is not hazardous to children's health and psychological development, frequently many children who are engaged in work usually do not go to school. ILO Convention 182 states that child labor that interferes with children's schooling is considered as the worst forms of child labor which violates rights to development of children. 
Meerza and Bacher (2011) found the two main reasons named poverty and illiteracy leading child labor. Bunnak (2007), who studied worst form of child workers in Cambodia in his study he described the working and living conditions, factors affecting the development of children and recommended how to eliminate the worst form of child labor in brick factories. The socioeconomic condition of the child laborer of the country compels the poor families to engage their children in risky jobs at an early age. They do not have interest in education as, they think, it has no real life necessity for them which is studied by Uddin, Hamiduzzaman and Gunter (2009) by focusing on child labor and educational issues.

Brown (2012) builds a linkage between child labor and educational disadvantages. This study expressed that strategies for the eradication of child labor have to tackle the problem in an integrated fashion, combining more stringent enforcement of rules and incentives to combat poverty with improved education provision internationally. The Government's Poverty Reduction Strategy Paper (2005) includes as a strategic goal taking immediate and effective measures to eliminate the worst forms of child labor, with a target of increasing the knowledge base about child labor and children's rights, and a future priority of legal reform to bring all child labor legislation in line with international standards.

According to Bangladesh Bureau of Statistics (2009) the joint ILO, UNICEF and UNESCO report on child labor and education in Bangladesh, Current Practices and Policy Recommendations, in 2009, indicated that 4.9 million economically active children are not attending schools, $72 \%$ of them are male. It is also estimated that 2.4 million children are working and attending school. Around 837,000 of 3.2 million child laborers are attending and working. This would indicate that $73 \%$ of child laborers who should be at school are not enrolled or attending school.

A more significant study (Mamun, Mondal, Islam and Kabir, 2008) have investigated factors influencing health complications of child laborers and showed that increased working hours, more hazardous sectors and engaging in an early age at work cause more health complications than others.

Some studies concluded that child labor cannot be eliminated from Bangladesh unless policies address the realities of poverty, unemployment and unawareness of adult workforce (Kalam, 2007) and reduction of child labor would be possible through a well combination of different policies that includes employment generation for household, compulsory children's schooling, adult-literacy (Kalam, 2007) etc. Actually the lack of legal learning about child work causes the increasing of child labor.

\section{OBJECTIVES OF THE STUDY}

The main objective of this study is to examine the influence of school dropout on Human Development Index of Bangladesh. The specific objectives are outlined below:

- To measure the impact of school dropout on education index of Bangladesh.

- To measure the direct and indirect impact of education on HDI of Bangladesh.

- To find the reasons behind school dropout in Bangladesh.

- To put forward suggestions that may help to reduce the rate of school dropout.

\section{METHODOLOGY}

The study is exploratory in nature and based on both primary and secondary data. The sample population for this study is composed of 200 students who left their schools at different classes. A convenience sampling technique was used to collect primary data by means of a survey, using self-administrated questionnaires from 200 respondents. Appropriate statistical analyses were used to satisfy the major objectives of the study such as weighted average, mean score, standard deviation and coefficient of variation, bar diagram, pie chart, frequency curve etc with the help of standard statistical applications such as SPSS and MS Excel. 


\section{SAMPLE DISTRIBUTION}

Two hundred school dropouts were interviewed from different parts of Bangladesh. Details of the samples are given below.

\begin{tabular}{|l|l|l|l|l|}
\hline Dropout class & Total Number & Male & Female & Percentage \\
\hline Class 1 to 3 & 45 & 20 & 25 & $22.5 \%$ \\
\hline Class 4 & 50 & 20 & 30 & $25 \%$ \\
\hline Class 5 & 40 & 15 & 25 & $20 \%$ \\
\hline Class 6 to 7 & 30 & 10 & 20 & $15 \%$ \\
\hline Class 8 and above & 35 & 10 & 25 & $17.5 \%$ \\
\hline Total & 200 & 75 & 125 & $100 \%$ \\
\hline
\end{tabular}

Table 1: Distribution of sampled school dropouts in Bangladesh

\section{FINDINGS AND ANALYSIS}

Following are the findings based on the objectives of the study referring from the sources of Primary and Secondary data:

The Human Development Index (HDI) is a summary measure of average achievement in key dimensions of human development: a long and healthy life, being knowledgeable and have a decent standard of living. The HDI is the geometric mean of normalized indices for each of the three dimensions. Education is one of the major components of human development index. So development in education sector is must for the development of the country. But how much does education really matter when it comes to the economy? This research paper gives some key insight into this question, and it turns out schooling might have a bigger impact than even some of the staunchest education advocates have argued.

\begin{tabular}{|l|l|l|l|l|l|l|l|l|l|l|l|l|}
\hline Year & 1990 & 1995 & 2000 & 2005 & 2010 & 2011 & 2012 & 2013 & 2014 & 2015 & 2016 & 2017 \\
\hline HDI & .386 & .424 & .468 & .505 & .545 & .557 & .567 & .575 & .583 & .592 & .597 & .608 \\
\hline $\begin{array}{l}\text { Education } \\
\text { Index }\end{array}$ & .251 & .291 & .344 & .385 & .425 & .442 & .454 & .465 & .477 & .488 & .490 & .508 \\
\hline
\end{tabular}

Table 2: HDI and Education Index of Bangladesh (Source-UNDP)

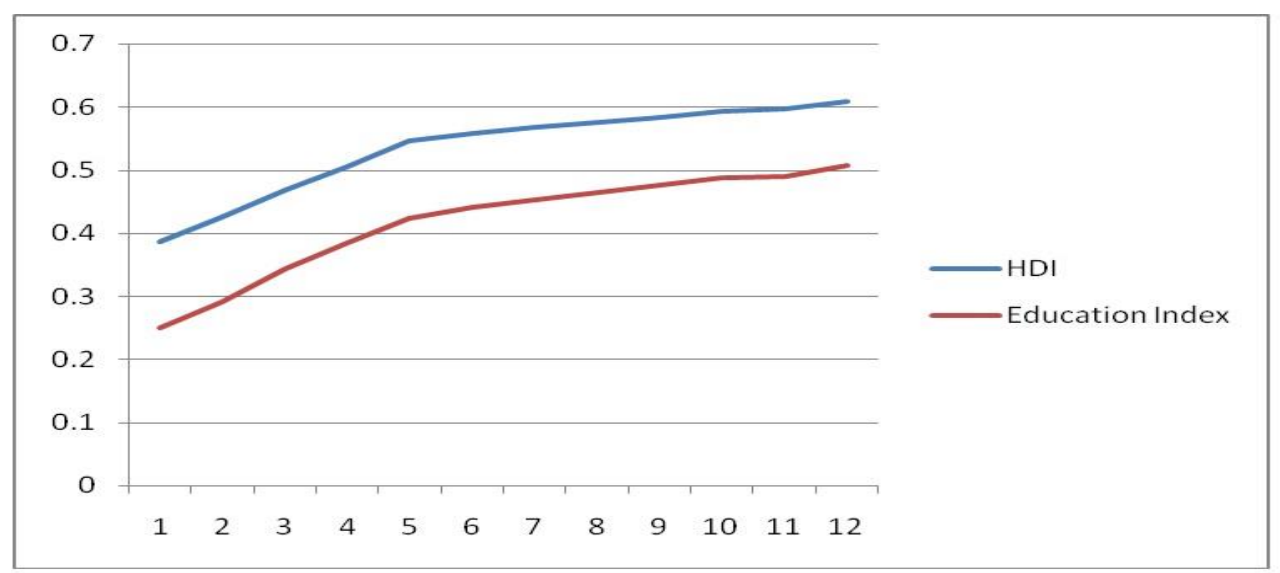

Fig: State of Bangladesh from 1990 to 2017

From the above gragh it is clearly shown that with the development of the education the HDI is also increasing and the data shows the correlation between Human Development Index and Education Index is 0.9 which is a strong positive correlation. So it is obvious that without the development in education sector the development of the country is impossible. School dropout plays a major role in country's Education Index. Findings of this research would be helpful for policy maker to control dropouts in educational institutes. 


\section{COMPARISON WITH NORWAY (1ST IN HDI):}

Graphical comparisons between the first positioning country Norway and $136^{\text {th }}$ positioning country Bangladesh on different categories in the year of 2017 are shown below (Ref: UNDP):
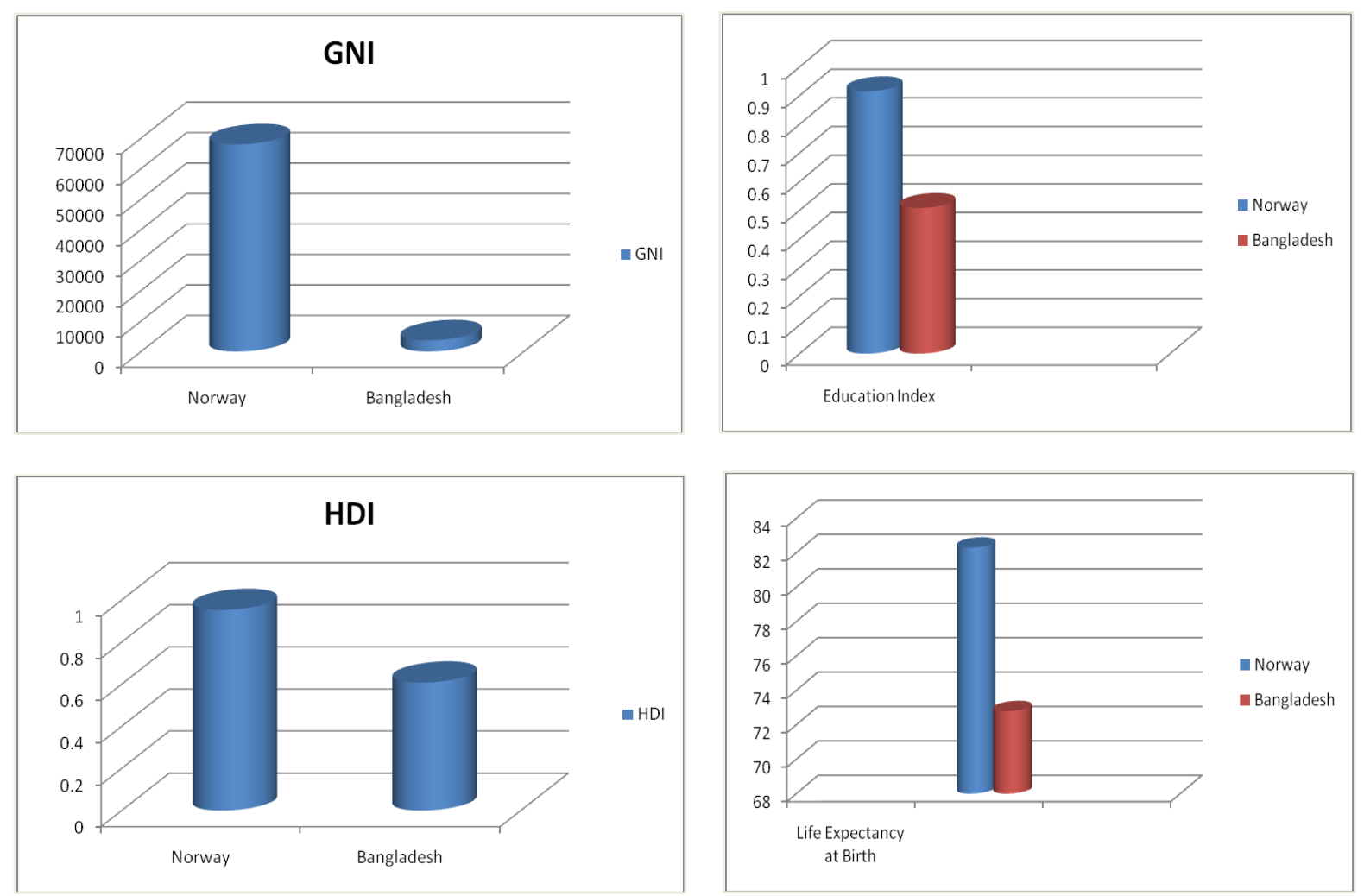

\section{IMPACT OF SCHOOL DROP OUT ON EDUCATION INDEX}

The Human Development Index (HDI) is the geometric mean of normalized indices for each of the three dimensions: Education Index, Life expectancy at birth and Gross National Income (GNI) per capita. According to Human Development Report (HDR), 2018, Bangladesh is categorized as "Medium human development" country, and achieved an HDI value of 0.608 in 2017.

Education index is one of the important components of HDI of a country. The lack of education, forces the poor household to engage in less productive activities which results in lower GNI. Thus we can see that education has both direct and indirect influence on HDI of a country. Education index is the function of mean year of schooling and expected year of schooling. The Education Index (EI) is calculated from the Mean years of schooling (MYS) and the Expected years of schooling (EYS). 'Mean years of schooling' is indexed by dividing by 15 and 'Expected years of schooling' is indexed by dividing by 18 . It is obtained by averaging these two indices. EI, Life expectancy index and income index together comprise of Human Development Index (HDI).

We calculate Education Index as follows

$\mathrm{EI}=((\mathrm{MYS} / 15)+(\mathrm{EYS} / 18)) / 2$

EI=Education Index

MYS=Mean Year of Schooling

EYS=Expected Year of schooling 
For the calculation of MYS that persons with incomplete primary education will be considered to be spent on average one-half of the duration of the primary level of education in school. For example, if the official duration of primary education (as defined in accordance with ISCED) is 6 years, then persons with incomplete primary education are assumed to have spent 3 years at that level even if he dropped out at class 6 . Thus school dropout is playing a vital role in calculating the mean year of schooling and education index as well.

\section{REASONS BEHIND SCHOOL DROPOUT}

\begin{tabular}{|l|l|l|}
\hline Reasons of school dropout & Number of Respondents & Percent \\
\hline Poor economic condition & 110 & $55 \%$ \\
\hline Poor performance in school & 10 & $5 \%$ \\
\hline Less interest of parents & 10 & $5 \%$ \\
\hline Lack of school facilities & 10 & $5 \%$ \\
\hline Broken families & 5 & $2.5 \%$ \\
\hline Early Marriage & 30 & $15 \%$ \\
\hline Migration of parents & 10 & $5 \%$ \\
\hline Adolescence offense & 15 & $7.5 \%$ \\
\hline Total & 200 & $100 \%$ \\
\hline
\end{tabular}

Table-3: Reasons behind school dropout

In the present study it is found that the main reasons of school dropouts of the children are the poor economic conditions (55\%), poor performance in school (5\%), less interest of parents $(5 \%)$, and lack of school facilities (5\%), broken family $(2.5 \%)$, early marriage (15\%) migration of parents $(5 \%)$ and getting involved in adolescence offense (7.5\%).

\section{DISCUSSION ABOUT THE REASONS BEHIND SCHOOL DROPOUT:}

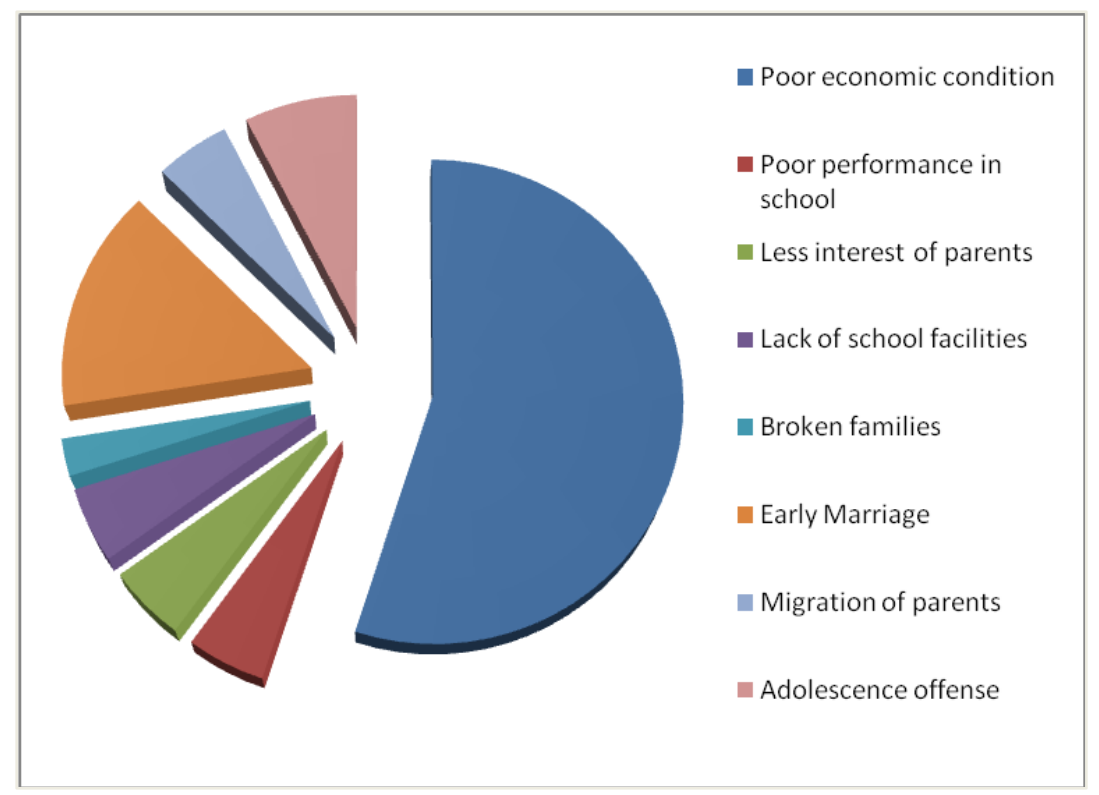

Figure: Reasons behind school dropout

The above figure clearly shows us the reasons behind school dropout in Bangladesh. These reasons are discussed below:

\section{POOR ECONOMIC CONDITION}

There is no single factor responsible for school dropout in the present study. This indicated that most of the child laborer's families are still under below poverty line. Inadequate income forces parents to 
put their children in the labor force. A large number of children had left their school in first and second standard due to their poor economic condition of whom they are from the rural migrants family. Those migrant's children are also being affected by their parent's shifting occupation.

\section{POOR PERFORMANCE IN SCHOOL}

In the present study 10 children out of 200 have left their school education due to poor performance in school. As a result, children face more difficulties in studying a subject like Mathematics at primary level and English language at middle school level and failed in the respective examinations. Under such circumstances children are neither protected by their parents or their teacher, they always preferred job than the education.

\section{LESS INTEREST OF PARENTS IN CHILD EDUCATION}

During the course of interviewing, it was found that the educational status of parents is very poor. In most of the cases the mothers are totally illiterate, yet they knew the importance of educating their children. But due to economic pressures, they were compelled to send their children out for work. Ultimately children from poor families divert to the urban area and prefer jobs in hotel establishments. School dropout is not only because of the large size of family and poverty, but it also found due to broken family and marital problems.

\section{LACK OF SCHOOL FACILITIES}

Another important reason behind discontinuation of education of respondents was non availability of school education in their respective native places. Most of the children came to Dhaka city from rural area. In this interior part only private schools are available which are very expensive. Therefore most of the respondents discontinued their middle schools and had joined in different sectors as a child labor.

\section{BROKEN FAMILY}

Nearly 2.5 percent of the respondents belonged to broken families. It means such respondent's parents had family problems. Some respondents said that due to father's addiction and frequent quarrels between mother and father motivated in accepting employment. Under such circumstances children lived with mother and discontinued their school education. There are so many other reasons of broken families which affected primary education of the respondents.

\section{MIGRATION OF PARENTS}

Migration of parents is another reason of school dropout of the respondents. Every year some respondent's parents left their native place and went to another place for employment during harvest season. These families stay in the field without caring their children for more than three months.

\section{GETTING INVOLVED IN ADOLESCENCE OFFENSE}

In the present study it is found that about $7.5 \%$ students left the school getting addicted by drug or adolescence offence which is very alarming.

\section{EARLY MARRIAGE}

In this study $15 \%$ of female students left their study for their early marriage.

\section{SUGGESTIONS AND RECOMMENDATION}

To control the worse satiation of students' dropouts from educational institutes Govt. should take some remedial measure, such as

- Community awareness seminar should be launch to develop the interest of parent and students towards study and avoid school dropout.

- Establishment of school with all basic Facilities such as; furniture, electricity, water and computer and science lab 
- Abolish Influences external powers from Schools which have adverse effect on educational system.

- Government should offer scholarships for intelligent and needy students.

- Study loan should be offered to provide financial support.

- Trends of early marriages should be abolish

- Improving working conditions for the children like as provide continued education, benefit leaves when sick, need protection device, increase wages and reduce workloads.

\section{LIMITATIONS}

This study also faces some limitations, such as time constraints and budget constraints. Due to these constrains this study cannot include causes of students' dropouts in rural areas and not able to conduct empirical testing.

\section{CONCLUSION}

This study explores the causes of students drop outs. On the basis of comparative analysis of different countries on reasons of students dropouts it was clear that students' dropouts in schools is not due to a single reason, there are different reasons of this problem but these reasons are similar in nature that cause students' dropouts in different countries. Poor economic condition of the family, early marriages, security problems and lack of school facilities are major causes of Students' dropouts. The major reason conducted by all the studies is weak financial and economic position of families and inability to afford educational expenditures, lack of basic facilities in schools like computer lab, science laboratory, library, electricity, clear drinking water and furniture. Low financial position reported as major cause of students' dropouts. Due to the early marriage Parents force their daughters to drop their school. Many poor parents bear children in order to enhance family income. Poverty and inadequate income forces parents to put their children in the labor force. Lack of parental motivation, high opportunity cost of schooling, broken families, orphanages, marital conflicts in a family, non-availability of school education in their respective native places, fear of the teacher and poor performance in school and also failing in a subject like Mathematics at primary level and English language at middle school level also contribute to aggravation of the problems of school dropout. Non-schooling of children has intimately connected with exploitation of child labor which is the consequence of social inequality, attitude of the privileged classes and lack of public involvement in the protection of basic entitlement. Migration of parents is another reason of school dropout of the respondents. Every year some respondent's parents left their native place to other place for their harvesting employment. Further it is suggested that necessary infrastructure, emotional support and environment for the same should be created by the government on behalf of civil society. If they feel that the education system is dull, unexciting, un-interesting and irrelevant the government should make sincere and earnest efforts, which should also be planned, coordinated and concerted to bring about a quantitative change and improvement in the content and process of education. The Government of Bangladesh has enacted several laws and policies in order to provide healthy, social and educational environment for the children. But in spite of all these laws and policies, problem of child labor still persists in our country and child labor is the main reason of school dropout. In global perspective, it is an incontestable fact that the progress of a nation is highly dependent on the education of their citizens. Education plays a central role and has a cross cutting impact on all aspects of human life. It is a vital investment for human and economic development. These findings would be helpful for making policies to promote quality education in country that will help to reduce illiteracy and increase literacy rate and economic progress. Quality education is most desirable objective of a country. It is fact that the country will grow where a large proportion of its budget is allocated on education. So necessary steps should be taken to reduce the rate of school dropout and hence make a remarkable development of this country. 


\section{References}

Bangladesh Bureau of Statistics (2002-2003), Planning Division, Ministry of Planning, Government of the People's Republic of Bangladesh.

Bangladesh Bureau of Statistics (2009), Planning Division, Ministry of Planning, Government of the People's Republic of Bangladesh.

Bridgeland JM, Dilulio JJ, Morison KB (2006) The silent epidemic. New York: Civic Enterprises, LLC.

Brown, G. "Child Labor and Educational Disadvantages- Breaking the link, Building opportunity." The office of the UN special envoy for global education, London EC2PJF.

Bunnak, P.(2007) “ Child workers in Brick Factories: Causes and Consequences, A Research Study for campaign of combating the worst forms of child labor in Cambodia." Licadho and World Vision Cambodia.

Chuard D, Mingat A (1996) An analysis of dropout and student leaving in primary education in Pakistan. Manila, Philippines: Asian Development Bank (ADB).

Coleman JS (1988) Social Capital in the Creation of Human Capital. The American Journal of Sociology 94: 95-120.

Dorn S (1993) Origins of the "Dropout Problem". History of Education Quarterly 33: 353-373

Government of Bangladesh, (2005) Unlocking the Potential: National Strategy for Accelerated Poverty Reduction, Poverty Reduction Strategy Paper, Dhaka.

Haq R (2013) Over 27 million children out of school

Hossain, M. A. (2012) “ Socio-economic Problems of Child Labor in Rajshahi City Corporation of Bangladesh: A Reality and Challenges" Research on Humanities and Social Sciences, ISSN2224-5766, Vol-2, No-4.

Hossain, Md. Afzal (2012), "Socio-Economic Problems of Child Labor in Rajshahi City Corporation of Bangladesh: A Reality and Challenges".

https://www.dhakatribune.com/bangladesh/development/2018/09/15/bangladesh-moves-3-notches-up-in-human-development-index

ILO, (1999), Convention 182: Convention on the Worst Forms of Child Labor, Geneva, International Labor Organization.

ILO-IPEC, (2006) Preventing and Eliminating the Worst Forms of Child Labor in selected formal and informal sectors in Bangladesh, Final Technical Progress Report, Geneva, p-2.

Jeynes WH (2007) The Relationship between parental involvement and urban secondary school Academic achievement. Ameta-analysis, urban Education 42: 82-110

Jingrong L (2004) High Dropout Rates in Rural School.

Kalam, I.M.S. (2007) "Glimpse on Child Labor Situation in Dhaka City Corporation Area”, Brac University Journal, 4(1), pp. 19-29

Khan AA (2008) Recalling Aligarh and Udaipur Dawn

Martins G, Oswald AS, Comassetto SH, Kieling JO, Goncalves C, et al. (2006) A package of interventions to reduce school dropout in public schools in a developing country: A feasibility study. European Child \& Adolescent Psychiatry 8: 442-449.

Mohsin AO, Aslam M, Bashir F (2004) Causes of dropouts at the secondary level in the Barani areas of the Punjab (a case study of Rawalpindi district). Journal of Applied Sciences 4: 55-158.

Perter F. Orazem \& Victoria Gunnarsson (2003). Child labour, School attendance and performance: A review on ILO/IPEC working paper.

Policy Paper (2014): Out-of-school Children and Child Labour. Global March Against Child Labour.

Rani UR (2011) Reasons For Rising School Dropout Rates Of Rural Girls In India- An Analysis Using Soft Computing Approach. International Journal of Current Research 3: 140-143

Roderick M (1993) The path to dropping out: Evidence for intervention. Westport, CT: Auburn House

Saadi AM, Saeed M (2010) Perceptions of students, educators and principals about quality assurance of elementary teacher education. Journal of Educational Research 13: 92-104

Staff Writer (2007) Why Pakistani primary school students drop out

Todaro PM (1994) Economic development, 5th Edition .New York: Longman publishers.

Zarif T, Haider K, Ahmed AA, Bano F (2014) Probing Reasons of High Student Dropout Rate in Grade 5-6 at Public Schools of District Thatta, Sindh-Pakistan, Asian Journal of Social Sciences \& Humanities 3: 158-169. 